\title{
JIWA KEWIRAUSAHAAN DAN NILAI KEWIRAUSAHAAN MENINGKATKAN KEMANDIRIAN USAHA MELALUI PERILAKU KEWIRAUSAHAAN
}

\author{
Sukirman \\ Fakultas Ekonomi, Universitas Muria Kudus \\ skirman101@yahoo.com
}

\begin{abstract}
It is necessary to anticipate small businesses' difficulties by conducting an empirical study on the entrepreneurial spirit, entrepreneurial values, and assessment of entrepreneurial behavior that may affect the realization of independence efforts. This study aims to analyze the influence of entrepreneurial spirit and entrepreneurial values on entrepreneurial behavior to create business independence. Our sample of 125 small business owners consist of 45 Pekalongan batik business owners, 42 small producers of typical Malang (Batu) food, and 38 ceramics business owners from Kasongan Bantul Yogyakarta. We use path analysis of Structural Equation Modelling (SEM) to analyze our date. The findings show that the entrepreneurial spirit has a direct positive influence on entrepreneurial behavior and positive indirect effect on the business independence. Further, entrepreneurial values have a direct impact on entrepreneurial behavior and also a positive indirect effect on the independence of the business. Meanwhile, entrepreneurial behavior has a positive effect on independence of business.
\end{abstract}

Keywords: entrepreneurial spirit, entrepreneurial values, entrepreneurial behavior, independence effort.

\begin{abstract}
ABSTRAK
Kesulitan usaha kecil perlu diantisipasi dengan melakukan tindakan pengujian empirik melalui kajian terhadap jiwa kewirausahaan, nilai kewirausahaan, dan kajian perilaku kewirausahaan yang dapat mempengaruhi proses terwujudnya kemandirian usaha. Penelitian ini bertujuan untuk menganalisis pengaruh jiwa kewiruasahaan dan nilai kewirausahaan terhadap perilaku kewirausahaan untuk menciptakan kemandirian usaha. Metode yang digunakan dalam menganalisis data menggunakan Analisis Jalur (Path Analysis). Sampel dalam penelitian ini 125 pelaku usaha kecil yang terdiri dari 45 pelaku usaha kecil batik Pekalongan, 42 usaha kecil makanan khas Batu Malang dan 38 usaha kecil keramik Kasongan Bantul Yogyakarta. Analisis data menggunakan Structural Equation Modelling (SEM). Hasil pengujian menunjukkan bahwa jiwa kewirausahaan mempunyai pengaruh secara langsung terhadap perilaku kewirausahaan dan pengaruh tidak langsung terhadap kemandirian usaha. Nilai kewirausahaan mempunyai pengaruh langsung terhadap perilaku kewirausahaan dan juga berpengaruh tidak langsung terhadap kemandirian usaha. Sedangkan perilaku kewirausahaan berpengaruh positif terhadap kemandirian usaha.
\end{abstract}


Kata kunci: jiwa kewirausahaan, nilai kewirausahaan, perilaku kewirausahaan, kemandirian usaha.

\section{PENDAHULUAN}

Pertumbuhan ekonomi negara-negara Asia Tenggara (ASEAN) khususnya Indonesia, Malaysia, Filipina, Singapura, Thailand dan Vietnam, mencapai 5 persen pada tahun 2011, dan ditargetkan menjadi 5,6 persen selama tahun 2012-2016, 2 persen lebih rendah dibanding tahun 2010. Permintaan dari luar tidak tumbuh terlalu banyak, maka ekonomi ASEAN beralih ke penggerak pertumbuhan domestik dalam jangka menengah dan mulai menggali sebagai strategi alternatif untuk perkembangan jangka panjang. Ketidakpastian global dan tantangan baru, sifat pertumbuhan di Asia berubah menjadi lebih seimbang. Jenis baru pertumbuhan ekonomi dibutuhkan di Asia Tenggara, ketidakpastian global adalah peluang untuk menciptakan ulang pertumbuhan (Pezzini 2012).

Untuk mencapai pertumbuhan ekonomi di Indonesia dalam ketidakpastian global, perlu melakukan pemberdayaan usaha kecil yang dianggap mampu mengembangkan produksi. Sesuai dengan program pemerintah ditargetkan 5 juta wirausaha baru sampai dengan 2025 dengan mengembangkan sumber daya manusia untuk kemajuan wirausaha nasional. Terdapat empat masalah pokok dalam pengembangan kewirausahaan nasional, terutama sektor kecil, dan menengah, diantaranya adalah terkait dengan akses pembiayaan, akses pemasaran, regulasi birokrasi, dan kapasitas UKM. Upaya peningkatan kapasitas wirausaha, pemerintah berupaya untuk meningkatkan kualitas sumber daya manusia dalam kewirausahaan dengan tiga tahap, yaitu pembibitan, penempaan, dan pengembangan.

Kewirausahaan tertuang dalam Peraturan Menteri Negara Koperasi dan UKM, Nomor: 06/Per/M.KUKM/VIII/ 2012 dengan harapan untuk mendorong dan mengakselerasi pemberdayaan Koperasi dan UMKM serta meningkatkan daya saing. Usaha kecil merupakan tumpuan yang diharapkan untuk mengambil strategi dengan menjadikan usaha yang mandiri, sehat, kuat, berdaya saing serta mengembangkan diri untuk meningkatkan pertumbuhan ekonomi, serta mendukung perluasan kesempatan kerja dalam mewujudkan demokrasi ekonomi. Peningkatkan kualitas kelembagaan dilakukan secara berjenjang melalui upaya membangunkan (awakening), pemberdayaan (empowering), pengembangan (developing), penguatan (strengthening).

Permasalahan dari berbagai penjuru menimpa pelaku usaha kecil, diantaranya adalah organisasi lemah, pemasaran sulit, modal usaha kecil, jiwa kewirausahaan rendah, kurang memperhatikan lingkungan dan layanan kurang baik (Sukirman 2010). Keterpurukan usaha kecil tidak terlepas dari ketergantungan terhadap pemerintah, perilaku kewirausahaan tanpa didasari kemampuan dalam mengelola 
usaha, serta regulasi di sektor usaha kecil yang dipandang belum mampu mendorong terciptanya pengelolaan usaha kecil yang dinamis dan inovasi.

Perilaku kewirausahaan memperlihatkan kemampuan pengusaha untuk melihat ke depan, berfikir dengan penuh perhitungan, mencari pilihan dari berbagai alternatif masalah dan pemecahannya masih kurang Suseno (2008). Pelaku usaha kecil sudah memiliki sikap proaktif dan inisiatif yang bagus dalam mengembangkan usaha. Pengetahuan kewirausahaan, motif berprestasi, kemandirian pribadi mempunyai daya dukung secara signifikan terhadap kemandirian usaha (Qamariyah \& Dalimunthe 2012). Pelaku usaha kecil dalam aspek orientasi prestasi dan komitmen dengan pihak lain masih kurang baik, hal ini ditunjukkan dari tidak munculnya kemauan untuk mengembangkan produk baru serta ketergantungan pada pihak-pihak yang berkepentingan termasuk pemerintah (Suseno 2008). Ketidakmampuan dalam persaingan serta rendahnya tingkat pengelolaan perilaku kewirausahaan merupakan tantangan bagi pelaku usaha kecil untuk mampu tumbuh dan berkembang menuju kemandirian usaha. Pada sisi lain diperlukan adanya pertumbuhan usaha kecil yang didasari pada nilai-nilai kewirausahaan dan jiwa kewirausahaan dengan harapan mampu membentuk perilaku usaha kecil dalam meningkatkan pertumbuhan ekonomi nasional. Oleh karena itu perlu adanya strategi pemberdayaan usaha kecil menuju kemandirian usaha dengan pendekatan jiwa kewirausahaan, nilai kewirausahaan dan perilaku kewirausahaan.

Tujuan dalam penelitian ini adalah untuk memberi bukti empiris sejauh mana jiwa dan nilai kewirausahaan mempengaruhi terbentuknya kemandirian usaha dari aspek jiwa kewirausahaan, nilai kewirausahaan, perilaku kewirausahaan, dan kemandirian usaha. Hasil kajian akan memberikan output tentang pemberdayaan usaha kecil menuju kemandirian usaha, yang memuat strategi pengelolaan jiwa kewirausahaan, strategi pengelolaan nilai kewirausahaan, dan strategi pengelolaan perilaku kewirausahaan.

\section{KAJIAN PUSTAKA DAN PENGEMBANGAN HIPOTESIS}

Undang-Undang No 20 tahun 2008 tentang Usaha Mikro, Kecil dan Menengah, memberi batasan bahwa usaha kecil merupakan usaha ekonomi produktif yang mandiri, dilakukan oleh perseorangan atau badan usaha yang bukan anak perusahaan atau cabang perusahaan yang dimiliki, dikuasai, atau menjadi bagian baik langsung maupun tidak langsung dari usaha menengah atau usaha besar, memiliki kekayaan bersih lebih dari Rp50.000.000,00 (lima puluh juta rupiah) sampai dengan Rp500.000.000,00 (lima ratus juta rupiah) tidak termasuk tanah dan bangunan tempat usaha; atau memiliki hasil penjualan tahunan lebih dari Rp300.000.000,00 (tiga ratus juta rupiah) sampai dengan paling banyak Rp2.500.000.000,00 (dua milyar lima ratus juta rupiah). 
Terwujudnya usaha kecil didasari adanya jiwa kewirausahaan yang merupakan kepribadian dan telah terinternalisasi melalui nilai-nilai kewirausahaan bagi orang yang melakukan kegiatan usaha. Jiwa kewirausahaan meliputi kepribadian yang memiliki tindakan kreatif sebagai nilai, gemar berusaha, tegar dalam berbagai tantangan, percaya diri, memiliki self determination atau locus of control, berkemampuan mengelola risiko, perubahan dipandang sebagai peluang, toleransi terhadap banyaknya pilihan, inisiatif dan memiliki need for achievement, perfeksionis, berpandangan luas, menganggap waktu sangat berharga serta memiliki motivasi yang kuat, dan karakter itu telah menginternalisasi sebagai nilai-nilai yang diyakini benar (Kuratko 2003). Jiwa kewirausahaan merupakan nyawa kehidupan dalam kewirausahaan yang pada prinsipnya merupakan sikap dan perilaku kewirausahaan dengan ditunjukkan melalui sifat, karakter, dan watak seseorang yang memiliki kemauan dalam mewujudkan gagasan inovatif kedalam dunia nyata secara kreatif (Hartanti 2008). Faktor-faktor yang mempengaruhi jiwa kewirausahaan seseorang diantaranya adalah: percaya diri (keyakinan), optimisme, disiplin, komitmen, berinisiatif, motivasi, memiliki jiwa kepemimpinan, suka tantangan, memiliki tanggung jawab, dan human relationship (Nasution 2007: 42-44; Suryana 2006:3).

Nilai-nilai kewirausahaan merupakan prasyarat yang berhubungan dengan perilaku kewirausahaan, (Frederick et al., 2006; Kickul \& Gundry, 2002; Schein 2001). Nilai-nilai tersebut terdiri atas kreativitas, pengambilan risiko, inovasi, berorientasi prestasi, ambisi, dan kemerdekaan Boohene et al. (2008). Nilai dalam menjalankan bisnis mengandung unsur pertimbangan yang mengembangkan gagasan-gagasan seorang pribadi atau sosial, maka lebih dipilih dibanding dengan bentuk perilaku atau bentuk akhir keberadaan perlawanan atau kebaikan. Nilai menjadi dasar dalam memahami sikap dan motivasi serta nilai mampu mempengaruhi persepsi perilaku dalam menjalankan bisnis, oleh karena itu nilai sangat penting untuk dipelajari dalam mengelola perilaku organisasi (Robbins 2007). Salah satu sumber yang dimiliki perusahaan skala kecil dan menengah adalah nilai kepribadian seseorang wirausaha, yaitu nilai-nilai kepribadian yang melekat pada diri seseorang pemilik yang sekaligus pimpinan perusahaan. Nilai yang dianut dalam menjalankan suatu bisnis pada umumnya merupakan nilai-nilai kewirausahaan (Alma 2001). Kewirausahaan merupakan kemampuan kreatif dan inovatif yang dijadikan dasar, dan sumber daya untuk mencari peluang menuju sukses. Proses kreatif hanya dilakukan oleh orang-orang yang memiliki kepribadian kreatif dan inovatif, yaitu orang yang memiliki jiwa, sikap, dan perilaku kewirausahaan, dengan ciri-ciri: penuh percaya diri, indikatornya adalah penuh keyakinan, optimis, berkomitmen, disiplin, bertanggung jawab; memiliki inisiatif, indikatornya adalah penuh energi, cekatan dalam bertindak, dan aktif; memiliki motif berprestasi, indikatornya terdiri atas orientasi pada hasil dan wawasan ke depan; memiliki jiwa kepemimpinan, indikatornya adalah berani tampil beda, dapat 
dipercaya, dan tangguh dalam bertindak; berani mengambil risiko dengan penuh perhitungan (Suryana 2006).

Sekumpulan aktivitas perusahaan dalam mengembangkan inovasi, pencarian usaha baru (venturing), dan pembaharuan strategik (strategic renewal) merupakan bagian dari perilaku kewirausahaan (Guth \& Ginsberg 1990). Konsep kewirausahaan yang dilihat sebagai fenomena pada level perusahaan mengarah kepada perilaku perusahaan, pengambilan risiko, upaya inovatif, dan penetapan strategi yang proaktif. Perubahan kebutuhan pelanggan, perubahan industri, munculnya persaingan, perubahan nilai sosial dan demografi, teknologi baru dan inovasi akan menciptakan banyak ketidakpastian serta seringkali mengharuskan organisasi untuk bereaksi dengan melakukan banyak perubahan yang meningkatkan risiko atau kemungkinan gagal. Organisasi tidak selalu hanya secara pasif melakukan reaksi atas perubahan lingkungan, namun juga terlibat langsung dalam perubahan lingkungan (Welsch et al., 2003). Kepekaan didefinisikan sebagai kemampuan yang proaktif, reaktif untuk menggunakan komponen yang ada dalam melakukan perubahaan sesuai dengan kondisi lingkungan. Perubahan lingkungan yang cepat dan didukung dengan adanya informasi yang mudah diperoleh, perusahaan harus membangun kemampuan untuk siap siaga dan memiliki kepekaan menghadapi hal tersebut (Zaheer 2001). Kepekaan organisasi diartikan bagaimana organisasi merespon kebutuhan pelanggan, baik saat ini maupun di massa yang akan datang, berdasarkan informasi yang diperoleh (Kohli \& Jaworski 1990). Keberhasilan perusahaan dalam lingkungan yang berubah cepat ditentukan oleh kemampuan dan kecepatan memberikan respon untuk menetapkan keputusan yang tepat, seiring sejalan dengan informasi yang diperoleh (Eisenhardt \& Martin 2000).

Kemandirian usaha yang terbentuk bagi pelaku usaha kecil merupakan sikap dan kondisi usaha yang memiliki semangat entrepreneurship untuk semakin mampu memenuhi kebutuhan dengan mengandalkan kemampuan dan kekuatan sendiri (pasal 1 ayat 8 Permen KUKM N0: 02/Per/M.KUKM///2008). Pengembangan usaha kecil yang tangguh dan mandiri dengan tujuan mempermudah, memperlancar dan memperluas akses usaha kecil kepada sumberdaya produktif agar mampu memanfaatkan kesempatan yang terbuka dan potensi terhadap sumberdaya lokal serta menyesuaikan skala usaha sesuai dengan tuntutan efisiensi (Siswoyo 2009). Sistem pengembangan usaha kecil dibangun dengan melalui pengembangan pendukung jasa pengembangan usaha yang terjangkau, semakin tersebar dan bermutu untuk meningkatkan akses usaha kecil terhadap pasar, dan sumberdaya produktif, seperti sumber daya manusia, modal, pasar, teknologi dan informasi termasuk mendorong peningkatan intermediasi lembaga keuangan. Sebagian besar pengusaha kecil di Indonesia mempunyai alasan berusaha karena adanya peluang bisnis dan pangsa pasar yang aman serta besar (Tambunan 2012:6). Akibatnya usaha kecil lebih banyak muncul karena kemandirian dalam menjalankan usaha, walaupun 
masih terjadi beberapa kegagalan karena belum memiliki kemampuan dalam menyelenggarakan kegiatan bisnis.

Kebijakan strategis dan terpadu untuk mengembangkan sektor usaha kecil, ditetapkan dengan harapan menjadikan usaha kecil sebagai kekuatan ekonomi mandiri, mampu memberi kontribusi yang signifikan terhadap pendapatan domestik bruto. Penguatan lembaga pembiayaan serta kebijakan strategis dalam mengembangkan usaha sektor kecil merupakan kekuatan ekonomi yang mandiri untuk terbentuknya usaha kecil yang tangguh dan sehat (Sukirman \& Indrayani 2014).

Pemberdayaan masyarakat merupakan pola pikir untuk merubah kondisi masyarakat ke arah yang lebih maju. Program yang telah dilaksanakan di bidang usaha ekonomi khususnya pada sub bidang bantuan pembangunan dan ekonomi masyarakat, beserta dampak program pemberdayaan tersebut terhadap kemandirian usaha ekonomi masyarakat miskin diharapkan mampu meningkatkan kesejahteraan masyarakat (Basuki 2007). Akibatnya diperlukan adanya kerjasama yang baik antar pemerintah dan masyarakat dalam mewujudkan kemandirian untuk melaksanakan kegiatan usaha sebelum beralih ke pemberdayaan masyarakat berikutnya. Pemberdayaan yang dilaksanakan dapat meningkatkan kemandirian ekonomi terutama pada produktivitas dan pendapatan masyarakat yang mendapatkan bantuan (Kurniawati 2013).

Pilihan strategi dalam perusahaan kecil diimplementasikan berdasarkan tujuan pribadi dan keinginan pemilik yang didasarkan pada nilai-nilai pribadi pengelola usaha (Boohene, Sheridan, \& Kotey 2008). Nilai-nilai pribadi yang terkait dengan strategi yang proaktif, sering disebut sebagai nilai-nilai kewirausahaan, meliputi kreativitas, pengambilan risiko, inovasi, berorientasi prestasi, ambisi, dan kemerdekaan (Hodgetts \& Kuratko 2001; Kickul \& Gundry 2002; Boohene et al., 2008). Selain itu nilai-nilai kesetaraan, perlindungan sosial dan kasih sayang digambarkan sebagai stategi konservatif dan dikaitkan dengan tipe yang reaktif (Kotey \& Meredith 1997; Boohene et al., 2008).

Sifat kepribadian seorang wirausaha mempunyai pengaruh positif terhadap prestasi perusahaan, sebaliknya seseorang yang tidak mempunyai nilai kewirausahaan terdapat pengaruh negatif terhadap kinerja usaha. Selain itu membuktikan bahwa sifat kepribadian seorang wirausaha mampu mempengaruhi variasi prestasi perusahaan (Alma 2001). Sifat kepribadian yang tinggi seperti pengawasan internal yang tinggi, kesediaan menanggung risiko yang tinggi, keperluan berprestasi yang tinggi, selalu berusaha untuk memperbaiki diri ke arah yang lebih baik dengan merubah tata cara mengelola usaha. Prestasi usaha yang dikelola oleh wirausaha yang memiliki sifat wirausaha tinggi akan lebih baik dibandingkan dengan usaha yang dikelola oleh wirausaha yang memiliki sifat kepribadian wirausaha rendah (Alma 2001). 
Pemberdayaan berdasarkan tujuan, proses, dan cara-cara pemberdayaan (Suharto 2005:210) merupakan sebuah proses dimana orang menjadi cukup kuat untuk berpartisipasi dalam berbagi pengontrolan, dan mempengaruhi terhadap kejadian-kejadian serta lembaga-lembaga yang mempengaruhi kehidupan. Pemberdayaan menekankan bahwa orang memperoleh ketrampilan, pengetahuan, dan kekuasaan yang cukup untuk mempengaruhi kehidupan dan kehidupan orang lain yang menjadi keahliannya. Hubungan antar peran masing-masing stakeholder usaha kecil (Karsidi 2007) diharapkan mampu memberikan sumbangan yang signifikan bagi kemajuan usaha. Pemberdayaan usaha kecil perlu diberi motivasi dan manfaat dari berbagai peluang dan fasilitasi yang diberikan oleh berbagai pihak (stakeholder) karena tanpa partisipati, usaha kecil secara individu maupun kelompok akan berakibat gagalnya usaha pemberdayaan yang dilakukan.

Pelaku usaha mikro belum mampu memanfaatkan pengelolaan manajemen organisasi, sehingga memerlukan adanya bimbingan pengelolaan manajemen untuk mewujudkan terbentuknya jiwa kewirausahaan (Sukirman 2010). Selain itu struktur organisasi kurang jelas sehingga berdampak pada ketidak jelasan dalam mewujudkan kemandirian usaha, yang akhirnya saling melempar tanggung jawab apabila terjadi permasalahan dalam menjalankan usaha. Pengelolaan lingkungan pada industri kecil belum dilaksanakan secara maksimal, kaitannya dengan keterlibatan karyawan, kinerja lingkungan, kinerja perusahaan dan perilaku kewirausahaan (Sukirman 2012). Sehingga dibutuhkan adanya keterkaitan antara industri kecil dengan karyawan dalam meningkatkan kinerja lingkungan menuju keberhasilan terbentuknya perilaku kewirausahaan. Selain itu, pembinaan dan pengembangan usaha kecil dalam pembangunan ekonomi masih dirasakan sangat diperlukan untuk memacu terbentuknya nilai kewirausahaan dengan harapan mampu meningkatkan laju pertumbuhan perekonomian dalam upaya mensejahterakan masyarakat (Glendoh 2013). Pimpinan perusahaan termasuk usaha kecil perlu memiliki kemampuan melakukan manajemen survival agar usahanya tetap dapat hidup dan semakin meningkat. Hubungan antara proses perencanaan dan kinerja kelompok perusahaan kecil dalam pengembangan industi, menunjukkan bahwa perencanaan strategis mampu meningkatkan pengembangan perusahaan kecil dengan berdasarkan pada kelompok usaha yang mandiri (Bracker et al., 2006).

Berdasarkan pada pengertian dan konsep toritis maka kerangka pikir penelitian ditunjukkan pada Gambar 1. 


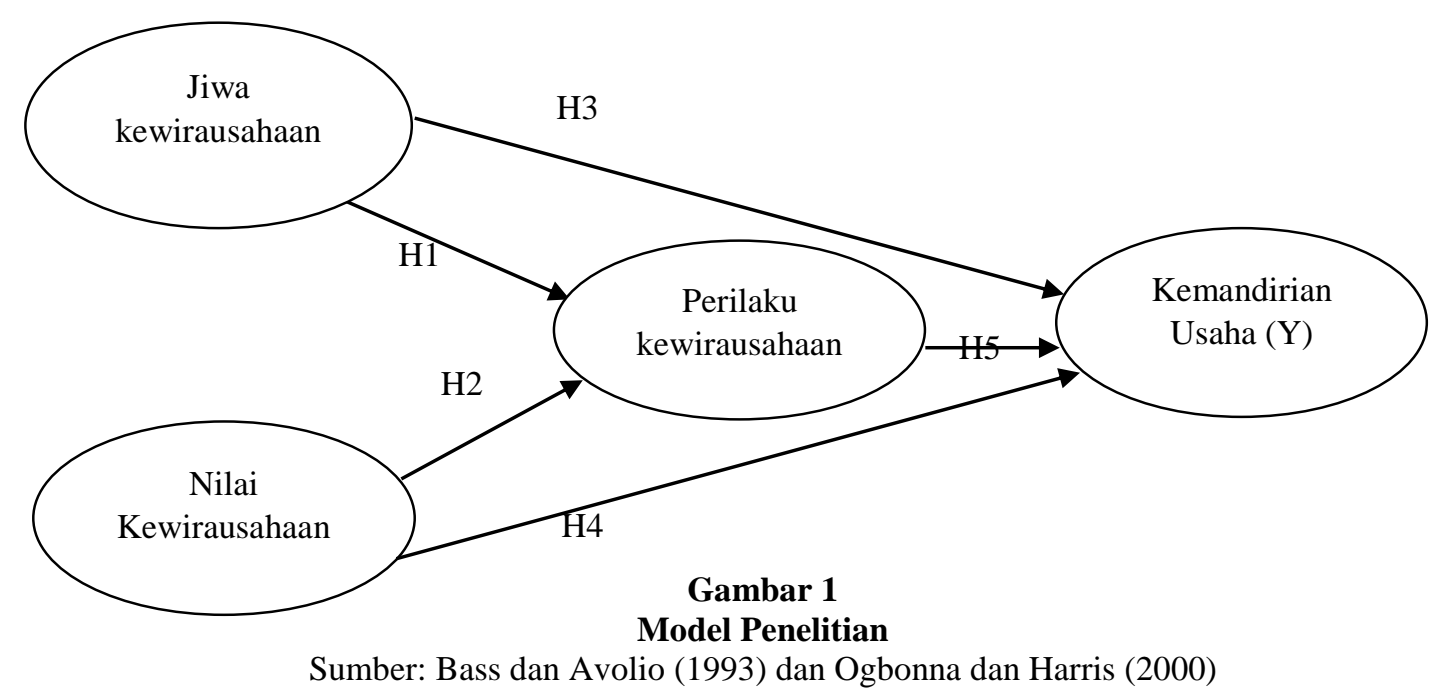

Hubungan Jiwa Kewirausahaan dengan Perilaku Kewirausahaan.

Jiwa kewirausahaan merupakan kepercayaan dan penerimaan yang kuat terhadap perilaku kewirausahaan, kemauan untuk bekerja keras, dan memelihara hubungan antar anggota, yang berarti ada keinginan yang kuat dari anggota untuk tetap berada dalam ikatan psikologis terhadap perusahaan. Kemampuan dalam menciptakan jiwa kewirausahaan akan meningkatkan perilaku kewirausahaan menjadi semakin tinggi. Jiwa kewirausahaan mempunyai pengaruh yang positif dan signifikan terhadap perilaku kewirausahaan (Silalahi 2007). Organisasi yang mempunyai pengetahuan kewirausahaan akan berkomitmen terhadap perilaku kewirausahaan untuk mendapatkan kemandirian dalam mengelola usaha kecil. Dengan argumentasi dan hasil sintesis riset terdahulu maka dapat dirumuskan hipotesis pertama sebagai berikut:

H1: Jiwa kewirausahaan mampu meningkatkan terwujudnya perilaku kewirausahaan bagi pelaku usaha kecil.

\section{Hubungan Nilai Kewirausahaan dengan Perilaku Kewirausahaan.}

Nilai-nilai kewirausahaan terdiri atas kreativitas, pengambilan risiko, inovasi, berorientasi prestasi, ambisi, dan kemerdekaan mampu menciptakan perilaku kewirausahaan yang kuat (Boohene, Sheridan, \& Kotey 2008). Kreativitas perusahaan akan mempengaruhi perilaku usaha kecil dalam menciptgakan inovasi untuk menuju kenerhasilan usaha yang lebih baik. Dengan argumentasi dan hasil riset terdahulu, maka hipotesis dua dinyatakan sebagai berikut:

H2: Nilai kewirausahaan mampu meningkatkan terwujudnya perilaku kewirausahaan bagi pelaku usaha kecil.

\section{Hubungan Jiwa Kewirausahaan dengan Kemandirian Usaha.}

Kehidupan dalam berwirausaha pada prinsipnya merupakan sikap dan perilaku kewirausahaan dengan ditunjukkan melalui karakter, dan watak seseorang yang memiliki kemauan dalam mewujudkan gagasan inovatif kedalam dunia nyata 
secara kreatif (Hartanti 2008). Karakter merupakan suatu kepribadian yang mampu memberikan pengaruh positif dan signifikan terhadap kemandirian usaha bagi pelaku usaha kecil (Astuti \& Sukardi 2013). Jiwa kewirausahaan yang tinggi diperlukan dalam menciptakan kemandirian usaha bagi pelaku usaha kecil. Berdasarkan argumentasi dan hasil riset terdahulu, maka disajikan hipotesis tiga sebagai berikut.

H3: Jiwa kewirausahaan mampu meningkatkan terwujudnya kemandirian usaha bagi pelaku usaha kecil.

\section{Hubungan antara Nilai Kewirausahaan dengan Kemandirian Usaha}

Nilai suatu kegiatan bisnis mengandung unsur pertimbangan yang memperluas gagasan-gagasan seorang, sehingga merupakan bentuk perilaku dalam menjalankan perusahaan menuju kemandirian usaha. Dasar dalam memahami sikap dan motivasi nilai kewirausahaan mampu mempengaruhi perilaku dalam menjalankan bisnis, sehingga nilai merupakan tingkah laku yang sangat penting dalam mengelola kemandirian perusahaan (Robbins 2007). Nilai kewirausahaan mempunyai pengaruh positif dan signifikan terhadap kemandirian usaha, oleh sebab itu peningkatan nilai yang tinggi terhadap pelaku usaha kecil mampu meningkatkan tumbuhnya kemandirian usaha (Djodjobo \& Tawas 2016). Dengan demikian, hipotesis empat diusulkan sebagai berikut.

H4: Nilai kewirausahaan mampu meningkatkan terwujudnya kemandirian usaha bagi pelaku usaha kecil.

\section{Hubungan Perilaku Kewirausahaan dengan Kemandirian Usaha}

Kebijakan strategis dalam mengembangkan sektor usaha kecil untuk menjadikan usaha kecil yang mandiri, dibutuhkan kemampuan dalam meningkatkan penguatan perilaku usaha dalam berbagai sektor. Penguatan perilaku kewirausahaan dalam mengembangkan usaha kecil merupakan kekuatan untuk terbentuknya usaha kecil yang mandiri, tangguh dan sehat. Kekuatan perilaku kewirausahaan mempunyai pengaruh yang positif dan signifikan terhadap kemandirian usaha bagi pelaku usaha kecil, artiya apabila tingkat perilaku kewirausahaan semakin baik maka kemandirian usaha bagi pelaku usaha kecil akan semakin meningkat (Silalahi 2007). Dengan merujuk pada hasil riset terdahulu dan argumentasi yang disajikan, maka dirumuskan hipotesis lima sebagai berikut.

H5: Perilaku kewirausahaan mampu meningkatkan terwujudnya kemandirian usaha bagi pelaku usaha kecil. 


\section{METODA PENELITIAN}

\section{Sampel dan Data Penelitian}

Sampel dalam penelitian ini menggunakan perbandingan jumlah indikator dengan jumlah sampel untuk analisis multivariat yaitu satu berbanding 5 sampai dengan 10 (Hair et al., 2011). Setiap indikator diperlukan minimal 5 dan maksimal 10 sampel. Jumlah sampel yang digunakan dalam penelitian ini menggunakan perbandingan 1 indikator berbanding 5 sampel. Dalam penelitian ini terdapat terdapat 25 indikator yang diubah menjadi pernyataan dalam kuesioner penelitian, sehingga jumlah sampel yang digunakan untuk penelitian adalah 125 responden.

Responden dalam penelitian ini adalah pelaku usaha kecil yang sudah berbentuk klaster dan terdaftar pada Dinas Koperasi dan UMKM di tiga wilayah yaitu Kabupaten Pekalongan, Kota Batu Malang dan Kasongan Bantul Yogyakarta. Populasi adalah 373 pelaku usaha kecil yang tersebar di tiga wilayah yaitu Kabupaten Pekalongan (136 usaha kecil), Kota Batu Malang (123 usaha kecil) dan Kasongan Bantul Yogyakarta (114 usaha kecil). Jumlah sampel ditentukan dengan menggunakan proportional sampling yang terdiri dari Kabupaten Pekalongan (45 responden), Kota Batu Malang (42 responden) dan Kasongan Bantul Yogyakarta (38 responden), dengan demikian jumlah seluruh sampel adalah 125 responden.

Tabel 1

Populasi dan Sampel

\begin{tabular}{lccc}
\hline \multicolumn{1}{c}{ Populasi } & Sampel & \multicolumn{2}{c}{ Jumlah } \\
\hline Kabupaten Pekalongan (136 UK) & Pelaku usaha & $36,5 \%$ & 45 \\
Kota Batu Malang (123 UK) & Pelaku usaha & $2,9 \%$ & 42 \\
Kasongan Bantul Yogyakarta (114 UK) & Pelaku usaha & $30,6 \%$ & 38 \\
Jumlah: 373 UK & & $\mathbf{1 0 0 \%}$ & $\mathbf{1 2 5}$ \\
\hline
\end{tabular}

Data sekunder diperoleh dari Badan Pusat Statistik dan Dinas Koperasi dan UMKM. Data diolah dengan menggunakan Structural Equation Modelling (SEM) dari paket software statistik AMOS. Uji validitas digunakan untuk mengukur suatu kuesioner, dikatakan valid apabila mampu mengukur nilai variabel yang diteliti. Validitas instrumen harus memiliki dua unsur, yaitu faktor ketepatan dan faktor kecermatan (Suliyanto 2006). Uji reliabilitas digunakan untuk mengukur sejauhmana hasil suatu pengukuran dapat dipercaya, apabila pengukuran dilakukan secara berulang hasilnya relatif sama, maka pengukuran tersebut dianggap memiliki reliabilitas tinggi (Suliyanto 2006).

Analisis kuantitatif dan pengujian hipotesis dilakukan dengan penyusunan model melalui: pengembangan model berbasis teori, menyusun diagram jalur (Path Diagram) dan diagram struktural, memilih jenis input matrik dan estimasi model yang diusulkan, menilai identifikasi model struktural, menilai kriteria goodnes-offit, interpretasi dan modifikasi model (Ghozali \& Fuad 2005). 
Tabel 2

Cara Perolehan Data

\begin{tabular}{|c|c|c|}
\hline Variabel & Indikator & Metode Perolehan Data \\
\hline $\begin{array}{l}\text { Jiwa } \\
\text { Kewirausahaan } \\
\text { (Nasution 2007; } \\
\text { Suryana 2006) }\end{array}$ & $\begin{array}{l}\text { 1. Percaya diri (kenyakinan), } \\
\text { 2. Optimisme, } \\
\text { 3. Disiplin, } \\
\text { 4. Komitmen, } \\
\text { 5. Berinisiatif, } \\
\text { 6. Motivasi, } \\
\text { 7. Memiliki jiwa kepemimpinan, } \\
\text { 8. Suka tantangan, } \\
\text { 9. Memiliki tanggung jawab, } \\
\text { 10. Human relationship. }\end{array}$ & $\begin{array}{l}\text { Kuesioner dan wawancara mendalam } \\
\text { dengan sasaran mengkaji indikator- } \\
\text { indikator penelitian yang diharapkan } \\
\text { mampu memberikan peningkatan jiwa } \\
\text { kewirausahaan terkait dengan konsep } \\
\text { pengembangan usaha kecil yang mandiri } \\
\text { dan tangguh. }\end{array}$ \\
\hline $\begin{array}{l}\text { Nilai } \\
\text { Kewirausahaan } \\
\text { (Boohene, } \\
\text { Sheridan, dan } \\
\text { Kotey 2008) }\end{array}$ & $\begin{array}{l}\text { 1. Kreativitas, } \\
\text { 2. Pengambilan risiko, } \\
\text { 3. Inovasi, } \\
\text { 4. Berorientasi prestasi, } \\
\text { 5. Ambisi, dan } \\
\text { 6. Kemerdekaan }\end{array}$ & $\begin{array}{l}\text { Kuesioner dan wawancaara mendalam } \\
\text { dengan mengkaji indikator-indikator } \\
\text { penelitian yang diharapkan dapat } \\
\text { meningkatkan nilai kewirausahaan dalam } \\
\text { menjamin kepastian usaha bagi pelaku } \\
\text { usaha kecil. }\end{array}$ \\
\hline $\begin{array}{l}\text { Perilaku } \\
\text { Kewirausahaan } \\
\text { (Guth dan } \\
\text { Ginsberg, 1990; } \\
\text { Zahra, 1996) }\end{array}$ & $\begin{array}{l}\text { 1. pencarian usaha baru } \\
\text { (venturing), } \\
\text { 2. pembaharuan strategik } \\
\quad \text { (strategic renewal) } \\
\text { 3. ketepatan kerja. } \\
\text { 4. Transparansi }\end{array}$ & $\begin{array}{l}\text { Mengkaji indikator-indikator penelitian } \\
\text { yang diharapkan mampu memperoleh sifat } \\
\text { perilaku kewirausahaan bagi pelaku usaha } \\
\text { kecil. }\end{array}$ \\
\hline $\begin{array}{l}\text { Kemandirian } \\
\text { Usaha }\end{array}$ & $\begin{array}{l}\text { 1. Mampu memenuhi sendiri } \\
\text { 2. Tidak mudah menyerah } \\
\text { 3. Berani mengambil keputusan } \\
\text { 4. Berani bersaing } \\
\text { 5.Menerima keunggulan pesaing }\end{array}$ & $\begin{array}{l}\text { Mengkaji indikator-indikator penelitian } \\
\text { yang diharapkan mampu membentuk } \\
\text { kemandirian usaha bagi pelaku usaha kecil. }\end{array}$ \\
\hline
\end{tabular}

Sumber: Boohene et al., 2008; Guth dan Ginsberg, 1990; Nasution, 2007; Suryana, 2006

\section{ANALISIS DAN PEMBAHASAN}

Uji validitas dan reliabilitas dibuktikan berdasarkan hasil analisis Cronbach's Alpha yaitu 0,685 ternyata lebih besar dari 0,6 artinya nilai tersebut lebih besar jika dibandingkan dengan nilai $r_{\text {tabel, }}$, sehingga nilai validitas dan reliabilitas instrumen menunjukkan bahwa kuesioner reliabel. Hasil pengujian validitas menunjukkan bahwa seluruh pernyataan valid karena nilai $r_{\text {hitung }}$ lebih besar dari nilai $r_{\text {tabel }}$ dan positif. Hasil pengujian validitas instrumen menunjukkan kuesioner tersebut valid.

Tabel 3

Uji Validitas dan Reliabilitas

Reliability Statistics

\begin{tabular}{cc} 
Cronbach's Alpha & N of Items \\
\hline 0,685 & 50 \\
\hline
\end{tabular}

Pengujian hipotesis menggunakan analisis SEM dengan tingkat signifikansi 5 persen, maka menghasilkan nilai Critical Ratio (CR) sebesar 1,96. Penerimaan 
hipotesis dilakukan apabila nilai t yang diperoleh $\geq 1,96$ dan nilai probabilitas kurang dari 0,05 atau tanda *** pada output AMOS. Sebaliknya hipotesis tidak didukung apabila nilai t yang diperoleh $\leq 1,96$ dan nilai probabilitas $>0,05$. Hasil uji hipotesis ditunjukkan pada tabel empat.

Tabel 4

Pengujian Hipotesis Model Penelitian.

\begin{tabular}{clccc}
\hline Hipotesis & \multicolumn{1}{c}{ Pernyataan Hipotesis } & Critical Ratio (CR) & Probability (P) & Hasil \\
\hline H1 & $\begin{array}{l}\text { Jiwa kewirausahaan berpengaruh } \\
\text { tehadap perilaku kewirausahaan }\end{array}$ & 2,486 & 0,002 & Didukung \\
H2 & $\begin{array}{l}\text { Nilai kewirausahaan berpengaruh } \\
\text { terhadap perilaku kewiraushaan }\end{array}$ & 4,832 & $* * *$ & Didukung \\
H3 & $\begin{array}{l}\text { Jiwa kewirausahaan berpengaruh } \\
\text { terhadap kemandirian usaha }\end{array}$ & 1,584 & 0,542 & Tidak \\
H4 & $\begin{array}{l}\text { Nilai kewirausahaan berpengaruh } \\
\text { terhadap kemandirian usaha }\end{array}$ & 0,673 & 0,865 & $\begin{array}{c}\text { Tidak } \\
\text { didukung } \\
\text { Didukung }\end{array}$ \\
H5 & $\begin{array}{l}\text { Perilaku kewirausahaan } \\
\text { berpengaruh terhadap } \\
\text { kemandiran usaha }\end{array}$ & 3,248 & 0,008 & D \\
\hline
\end{tabular}

Berdasarkan Tabel 4 menunjukkan bahwa jiwa kewirausahaan $(\mathrm{CR}=2,468$; $\mathrm{P}=0,002)$ dan nilai kewirausahaan $(\mathrm{CR}=4,832 ; \mathrm{P}=* * *)$ berpengaruh positif dan signifikan terhadap perilaku kewirausahaan. Sedangkan jiwa kewirausahaan $(\mathrm{CR}=1,584 ; \mathrm{P}=0,542)$ dan nilai kewirausahaan $(\mathrm{CR}=0,673 ; \mathrm{P}=0,865)$ tidak berpengaruh dan tidak signifikan terhadap kemandirian usaha. Namun demikian perilaku kewirausahaan $(\mathrm{CR}=3,248 ; \mathrm{P}=0,008)$ berpengaruh positif dan signifikan terhadap kemandirian usaha.

Pengaruh langsung hubungan antar variabel menunjukkan bahwa variabel yang memiliki pengaruh paling besar terhadap perilaku kewirausahaan adalah nilai kewirausahaan dengan kontribusi sebesar 46,2 persen. Variabel perilaku kewirausahaan berpengaruh besar tehadap variabel kemandirian usaha dengan kontribusi sebesar 68,4 persen.

Tabel 5

Direct Effects (Group number 1 - Default model)

\begin{tabular}{cccc}
\hline & $\mathbf{X}_{\mathbf{2}}$ & $\mathbf{X}_{\mathbf{1}}$ & $\mathbf{Y}_{\mathbf{1}}$ \\
\hline $\mathrm{Y}_{1}$ &, 462 &, 147 &, 000 \\
$\mathrm{Y}_{2}$ &, 008 &, 065 &, 684 \\
\hline
\end{tabular}

Pengaruh tidak langsung dalam penelitian ini disajikan dalam tabel 6 yang menunjukkan bahwa seluruh variabel eksogen memiliki pengaruh tidak langsung terhadap variabel kemandirian usaha. Pengaruh tidak langsung yang paling besar terhadap variabel kemandirian usaha adalah variabel nilai kewirausahaan dengan kontribusi sebesar 31,6 persen. 
Tabel 6

Indirect Effects (Group number 1 - Default model)

\begin{tabular}{cccc}
\hline & $\mathbf{X}_{\mathbf{2}}$ & $\mathbf{X}_{\mathbf{1}}$ & $\mathbf{Y}_{\mathbf{1}}$ \\
\hline $\mathrm{Y}_{1}$ &, 000 &, 000 &, 000 \\
$\mathrm{Y}_{2}$ &, 316 &, 204 &, 000 \\
\hline
\end{tabular}

Berdasarkan hasil pengujian dalam model penelitian ini pada hubungan antar variabel diperoleh pengaruh langsung dan pengaruh tidak langsung antar variabel, oleh karena itu diperlukan adanya pengukuran pengaruh total. Berdasarkan perhitungan, hasil pengukuran pengaruh total antar variabel ditunjukkan pada tabel 7 .

Tabel 7

Total Effects (Group number 1 - Default model)

\begin{tabular}{cccc}
\hline & $\mathbf{X}_{\mathbf{2}}$ & $\mathbf{X}_{\mathbf{1}}$ & $\mathbf{Y}_{\mathbf{1}}$ \\
\hline $\mathrm{Y}_{1}$ &, 462 &, 147 &, 000 \\
$\mathrm{Y}_{2}$ &, 324 &, 269 &, 648 \\
\hline
\end{tabular}

Berdasarkan hasil analisis dapat ditarik kesimpulan bahwa untuk membentuk kemandirian usaha bagi pelaku usaha kecil yang perlu dikembangkan adalah memberdayakan perilaku kewirausahaan pada pelaku usaha kecil dengan cara meningkatkan variabel yang paling dominan atau memiliki loading factor terbesar. Hal tersebut dilakukan dengan memperhatikan kembali nilai kewirausahaan dimulai dari membangun kepercayaan diri sendiri dengan membentuk keyakinan, optimis, berkomitmen, disiplin, dan bertanggung jawab dalam menjalankan suatu usaha. Selanjutnya diikuti dengan adanya keberanian untuk mengambil risiko melalui berbagai perhitungan yang tidak merugikan perusahaan. Selain itu dituntut adanya keberanian dalam menciptakan inisiatif dengan ditunjukkan adanya keaktifan, cekatan dan penuh inisiatif dalam berbisnis, didukung dengan adanya motif berprestasi melalui orientasi pada hasil dan wawasan ke depan, sesuai dengan penelitian yang dilakukan Silalahi (2007). Atas dasar tersebut maka perilaku kewirausahaan pada pelaku usaha kecil dapat ditingkatkan dengan cara mengembangkan kepercayaan dalam kepastian usaha melalui perlindungan usaha.

Hasil analisis penelitian ini memberi bukti empiris bahwa jiwa kewirausahaan berpengaruh positif dan signifikan terhadap perilaku kewirausahaan (hipotesis pertama terdukung). Kondisi ini menunjukkan bahwa jiwa kewirausahaan yang dimiliki pelaku usaha kecil mampu meningkatkan terbentuknya perilaku kewirausahaan, mendoronga serta menumbuhkan semangat bagi pelaku usaha kecil dalam menjalankan kegiatan usaha. Hasil penelitian ini mendukung penelitian Husaini (2004) yang mengatakan bahwa jiwa kewirausahaan berpengaruh positif dan signifikan terhadap perilaku kewirausahaan. Berarti pelaku usaha kecil diharapkan mengedepankan jiwa kewirausahaan dalam setiap kegiatan bisnis dengan sebaikbaiknya supaya dapat membentuk perilaku kewirausahaan yang kuat dan tangguh.

Nilai kewirausahaan berpengaruh positif dan signifikan terhadap perilaku kewirausahaan. Kondisi ini menunjukkan bahwa hipotesis kedua terdukung yaitu 
nilai kewirausahaan yang dikembangkan oleh pelaku usaha kecil mampu memberdayakan kegiatan bisnis demi kelangsungan usaha. Hasil penelitian ini sejalan dengan penelitian Choueke dan Armstrong (1988) bahwa nilai kewirausahaan berpengaruh kuat terhadap perilaku kewirausahaan. Berdasarkan hasil tersebut menunjukkan bahwa pelaku usaha kecil memiliki nilai kewirausahaan yang mampu meningkatkan perilaku kewirausahaan. Nilai kewirausahaan yang dimiliki pelaku usaha kecil mampu mewujudkan terbentuknya perilaku usaha melalui pengembangan usaha dan pengambilan keputusan yang dilakukan dalam menjalankan usaha. Keberanian untuk mengembangkan usaha serta pengambilan keputusan pada saat yang tepat sudah biasa dilakukan pelaku usaha kecil karena merupakan aktifitas yang harus dipilih agar perusahaan tidak mengalami kegagalan usaha.

Hasil penelitian ini juga menunjukkan bahwa jiwa kewirausahaan tidak mempunyai pengaruh terhadap kemandirian usaha (hipotesis ketiga tidak didukung). Hasil ini bertentangan dengan penelitian Basuki (2007) yang menunjukkan bahwa jiwa kewirausahaan berpengaruh positif dan signifikan terhadap kemandirian usaha. Apabila jiwa kewirausahaan semakin meningkat maka kemandirian usaha pelaku usaha kecil juga akan semakin kuat dan tangguh dalam menjalankan bisnis. Namun demikian walaupun jiwa kewirausahaan meningkat, tidak selalu akan menyebabkan terbentuknya kemandirian usaha bagi pelaku usaha kecil. Sehingga terbentuknya kemandirian usaha tidak tergantung pada baik atau buruknya jiwa kewirausahaan bagi pelaku usaha kecil. Tidak signifikannya pengaruh jiwa kewirausahaan terhadap kemandirian usaha bisa ditunjukkan karena sebagian besar responden dari analisis diskriptif mayoritas adalah pelaku bisis yang terbentuk secara turun temurun atas dasar bisnis keluarga.

Penelitian ini juga menunjukkan hasil bahwa nilai kewirausahaan tidak mempunyai pengaruh terhadap kemandirian usaha (hipotesis keempat tidak didukung). Semakin kuat nilai kewirausahaan bagi pelaku usaha kecil maka akan semakin kuat pula terbentuknya kemandirian usaha. Kondisi ini menunjukkan walaupun nilai kewirausahaan kuat tidak selalu membangkitkan terbentuknya kemandiran usaha bagi pelaku usaha kecil. Atas dasar temuan tersebut maka dapat disimpulkan bahwa terbentuknya kemandirian usaha tidak tergantung pada kuat atau lemahnya nilai kewirausahaan.

Hasil penelitian ini menunjukkan bahwa perilaku kewirausahaan berpengaruh positif dan signifikan terhadap kemandirian usaha (hipotesis kelima terdukung). Artinya apabila pelaku usaha kecil menunjukkan perilaku kewirausahaan yang kuat, maka akan semakin kuat juga terbentuknya kemandirian usaha. Hasil kajian ini sesuai dengan penelitian Haryono dan Khoiriyah (2012) yang menyatakan bahwa perilaku kewirausahaan berpenaruh positif dan signifikan terhadap terbentuknya kemandirian usaha. 
Jiwa kewirausahaan akan mengalami peningkatan secara signifikan terhadap kemandirian usaha secara tidak langsung dengan dimoderasi oleh perilaku kewirausahaan, hasil ini sesuai dengan penelitian yang dilakukan Amelia (2009). Sehingga prioritas yang diperlukan bagi pelaku usaha kecil dalam membentuk kemandirian usaha adalah dengan memberdayakan pelaku usaha kecil sebagai perwujudan dari perilaku kewirausahaan dengan menguatkan jiwa kewirausahaan yang baik. Hasil penelitian ini bertentangan dengan penelitian Frederick et al. (2006) yang menyatakan bahwa jiwa kewirausahaan berpengaruh postif dan signifikan terhadap terbentuknya kemandirian usaha.

Nilai kewirausahaan akan mengalami penguatan secara tidak langsung terhadap terbentuknya kemandirian usaha apabila dimoderasi perilaku kewirausahaan, sehingga perlakuan utama terhadap terbentuknya kemandirian usaha adalah perlu adanya peningkatan usaha dengan menciptakan rasa percaya diri serta pengembangan karir bagi pelaku usaha kecil demi terwujudnya perilaku kewirausahaan yang kuat. Hasil temuan ini tidak sejalan dengan penelitian Thobias (2013) yang menyatakan bahwa perilaku kewirausahaan mempengaruhi terbentuknya kemandirian usaha.

Walaupun terdapat hubungan yang tidak signifikan antara nilai kewirausahaan dan perilaku kewirausahaan terhadap kemandirian usaha, tetapi perilaku kewirausahaan memiliki peran yang sangat kuat untuk meningkatkan nilai signifikansi kedua variabel tersebut. Prioritas utama yang perlu dilakukan oleh pelaku usaha kecil adalah bagaimana untuk dapat menciptakan rasa percaya diri, berani mengambil keputusan dan melakukan penguatan untuk pengembangan usaha agar terbentuk kemandirian usaha yang signifikan di masa yang akan datang.

\section{SIMPULAN, KETERBATASAN DAN SARAN}

\section{Kesimpulan}

Penguatan jiwa kewirausahaan akan menimbulkan dampak pada penguatan perilaku kewirausahaan, juga peningkatan nilai kewirausahaan akan meningkatkan perilaku kewirausahaan. Peningkatan jiwa kewirausahaan mampu meningkatkan terbentuknya kemandirian usaha, tetapi belum menjadi sesuatu yang bermakna, artinya pelaku usaha kecil yang mampu meningkatkan jiwa kewirusahaan tidak serta merta akan membentuk kemandirian usaha. Penguatan nilai kewirausahaan mampu meningkatkan pembentukan kemandirian usaha, tetapi tidak mempunyai arti yang bermakna, karena jiwa kewirausahaan yang dibentuk oleh pelaku usaha kecil belum merupakan faktor yang memungkinkan untuk membentuk terjadinya kemandirian usaha. Sedangkan penguatan pada perilaku kewirausahaan mampu menciptakan terbentuknya kemandirian usaha bagi pelaku usaha kecil. 


\section{Keterbatasan Penelitian}

Isu strategis pemberdayaan usaha kecil yang ada menunjukkan bahwa persolaan kemandirian usaha masih merupakan beban bagi pelaku usaha kecil. Persoalan ini membutuhkan kesadaran psikologis yaitu kemampuan individu untuk memahami ransang-ransang timbul dari dalam dirinya maupun dari luar dirinya, melalui panca indera dan perhatiannya, sehingga individu tersebut mampu melakukan hubungan dan pembatasan yang baik dengan lingkungan, termasuk waktu, tempat, dan keadaan secara umum, atau dengan dirinya sendiri diantaranya pikiran, perasaan, atau kebutuhan-kebutuhan, dalam menyelenggarakan kegiatan bisnis.

Keterbatasan penelitian ini di antaranya adalah penelitian ini dilakukan pada perusahaan kecil yang terdaftar pada Dinas Kopersasi dan UMKM, sehingga masih dimungkinkan untuk dilakukan penelitian sejenis pada perusahaan lain yang lebih luas. Orientasi dalam penelitian ini terpusat pada strategi pemberdayaan usaha kecil utamanya yaitu kemandirian usaha, sementara itu masih terdapat aspek lain yang belum dijelaskan secara mendalam, sehingga diperlukan adanya berbagai variabel dan faktor lain untuk melengkapi penelitian ini.

\section{Saran}

Perlu adanya pemikiran dan tindakan yang komprehensif dalam menangani masalah-masalah pengelolaan usaha kecil dengan lebih meningkatkan keterlibatan masyarakat, stakeholders, dan pemerintah. Usaha kecil yang masih mengalami jiwa kewirausahaan rendah, diperlukan adanya pemgembangan keyakinan, optimisme, serta mampu membentuk komitmen dengan melalui disiplin, didukung dengan kemampuan membentuk motivasi yang dilandasi jiwa kepmimpinan dalam mengambil keputusan dengan keberanian mengambil risiko yang penuh tanggung jawab.

Pemberdayaan usaha kecil dengan mengelola jiwa kewirausahaan diharapkan dapat menciptakan pelaku usaha kecil yang mandiri, serta tangguh dalam menghadapi persaingan terutama dari produk-produk global yang saat ini membanjiri pasar domistik. Adanya perubahan pengelolaan nilai kewirausahaan bagi pelaku usaha kecil yang masih menggunakan pola kekeluargaan, supaya lebih dikembangkan model koperasi dengan harapan akan lebih efisien, efektif serta mengurangi kebiasaan-kebiasaan yang tidak mendukung terbentuknya kemandirian usaha.

Keterlibatan pemerintah daerah dilibatkan terutama dalam memberdayakan keahlian pelaku usaha kecil melalui pelatihan untuk produk-produk yang memerlukan ketrampilan khusus seperti desain batik, pengolahan hasil perkebunan, kerajinan sehingga akan menghasilkan produk yang berkualitas serta mempunyai daya saing tinggi. 
Kemandirian usaha kecil memerlukan perlindungan pengelolaan usaha agar dapat dengan mudah untuk menjalankan bisnis, oleh karena itu dibutuhkan peran serta pemerintah daerah, perguruan tinggi dan stakeholders untuk mewujudkan adanya peraturan daerah tentang pengelolaan usaha kecil yang dapat melindungi pelaku usaha kecil. Sehingga dapat meningkatkan produktifitas serta berdampak pada pertumbuhan usaha yang sinergis dalam menjamin kelangsungan hidup perusahaan.

\section{DAFTAR PUSTAKA}

Abdul Baten, Md. 2018. "Beyond the fraud triangle; why people engage in pecuniary crimes? Introduction." Int. J. Adv. Res 6 (1): 2320-5407. https://doi.org/10.21474/IJAR01/6313.

Alma, Buchari. 2001. Kewirausahaan. Bandung: Alfa Beta.

Amelia. 2009. "Pengaruh pengetahuan kewirausahaan dan kemandirian pribadi terhadap kinerja usaha (studi kasus pada pedagang pakaian pajak sore jalan jamin ginting)." FE Universitas Sumatera Utara.

Astuti, S, dan T. Sukardi. 2013. "Faktor-faktor yang mempengaruhi kemandirian untuk berwirausaha pada siswa SMK." Jurnal Pendidikan Vokasi 3 (3): 33446.

Bass, Bernard M, dan Bruce J Avolio. 1993. "Tansformational leadership and organizational culture bass." Public Administration Quarterly 17 (1): 112-21. https://doi.org/10.1080/01900699408524907.

Basuki, R. 2007. "Analisis hubungan antara motivasi, pengetahuan kewirausahaan, dan kemandirian usaha terhadap kinerja pengusaha pada kawasan industri kecil di daerah pulogadung." Jurnal Usahawan 2 (10): 1-8.

Boohene, Rosemond, Alison Sheridan, dan Bernice Kotey. 2008. "Gender, personal values, strategies and small business performance: A Ghanaian case study." Equal Opportunities International $27 \quad$ (3): $237-57$. https://doi.org/10.1108/02610150810860075.

Bracker, Jeffrey S., Barbara W. Keats, dan John N. Pearson. 2006. "Planning and financial performance among small firms in a growth industry." Strategic $\begin{array}{llll}\text { Management Journal } & 9 & \text { (6): }\end{array}$ https://doi.org/10.1002/smj.4250090606.

Choueke, Richard, dan Roger Armstrong. 1988. "The learning organisation in small and medium-size enterprises, a destination or a journey." International Journal of Entrepreneurial Behaviour \& Research 4 (2): 129-140. https://doi.org/10.1108/13552559810224585.

Djodjobo, Vanessa Cynthia, dan Hendra N Tawas. 2016. "Pengaruh orientasi 
kewirausahaan, inovasi produk, dan keunggulan bersaing terhadap kinerja pemasaran usaha nasi kuning di kota Manado.” Jurnal EMBA 2 (3): 1214-24.

Eisenhardt, K. M, dan J.A. Martin. 2000. "Dynamic capabilities: What are that?" Strategic Management Journal 15 ((Winter Special Issues)): 1105-21.

Frederick, H., Donald F. Kuratko, dan Richard M. Hodgetts. 2006. Entrepreneurship: theory, process and practice. Asia-Pacif. Cengage Learning Australia Pty Limited.

Ghozali, dan Fuad. 2005. Structural equation modeling teori konsep dan aplikasi dengan program Lisrel 8.54. Semarang: Badan Penerbit UNDIP.

Glendoh, S. H. 2013. "Pembinaan dan pengembangan usaha kecil." Jurnal Manajemen dan Kewirausahaan 3 (1): 1 - 13.

Guth, William D., dan Ari Ginsberg. 1990. "Corporate entrepreneurship (guest editors' introduction)." Strategic Management Journal 11: 5-15. https://doi.org/10.1016/j.ymeth.2009.12.016.

Hair, Joe F., Christian M. Ringle, dan Marko Sarstedt. 2011. "PLS-SEM: Indeed a Silver Bullet." The Journal of Marketing Theory and Practice 19 (2): 139-51. https://doi.org/10.2753/MTP1069-6679190202.

Hartanti. 2008. "Manajemen pengembangan kewirausahaan (entrepreneurship) siswa SMK 4 Yogyakara." Universitas Negeri Yogyakarta.

Haryono, Tulus, dan Siti Khoiriyah. 2012. "Pengaruh perilaku kewirausahaan terhadap kinerja usaha kecil dan menengah (studi kasus pada UMKM di Surakarta).” Jurnal Online Universitas Negeri Sebelas Maret.

Hodgetts, Richard M., dan Donald F. Kuratko. 2001. Effective small business management. Orlando FL: Harcourt College Publishers.

Husaini. 2004. "Pengembangan jiwa kewirausahaan melalui peningkatan pendidikan kejuruan di Kabupaten Indragiri Hilir." Sekolah Pascasarjana IPB Bogor.

Karsidi, R. 2007. "Pemberdayaan masyarakat untuk usaha kecil dan mikro (pengalaman empiris di wilayah Surakarta Jawa Tengah).” Jurnal Penyuluhan 3 (2): 136-45.

Kickul, Jill, dan Lisa K. Gundry. 2002. "Prospecting for strategic advantage: The proactive entrepreneurial personality and small firm innovation." Journal of Small Business Management 40 (2): 85-97. https://doi.org/10.1111/1540$627 X .00042$.

Kohli, Ajay K., dan Bernard J. Jaworski. 1990. "Market orientation: the construct, research propositions, and managerial implication." Journal of Marketing 54: 1-18. https://doi.org/10.2307/1251866.

Kotey, B, dan G. G. Meredith. 1997. "Relationship among owner/manager personal 
values and perceptions, business strategis, and enterpreise performance." Journal of Small Business Management 35 (2): 37-64.

Kuratko, D. F. 2003. "Kuratko, D. F. 2003. Entrepreneurship education: Emerging trends and challenger for the 21st century." Coleman Foundation White paper series for the US Association of small business and entrepreneurship.

Kurniawati, D.P. 2013. "Pemberdayaan masyarakat di bidang usaha ekonomi (studi pada badan pemberdayaan masyarakat kota Mojokerto." Jurnal Administrasi Publik 1 (4): 9-14.

Nasution, Arman Hakim. 2007. Entrepreneurship membangun spirit teknopreneurship. Yogyakarta: Andi Offset.

Ogbonna, E, dan L C Harris. 2000. "Leadership style, organizational culture and performance: Empirical evidence from uk companies." International Journal of Human Resource Management 11 (4): 766-88. https://doi.org/10.1038/166711a0.

Pezzini, Mario. 2012. “An Emerging midle class. Journal OECD Observer.” Journal OECD Observer.

Qamariyah, I, dan D. M. J. Dalimunthe. 2012. "Pengaruh pengetahuan kewirausahaan, motif berprestasi, dan kemandirian pribadi terhadap daya saing usaha (pengusaha kuliner skala kecil di jalan Dr. Mansur Medan)." Jurnal Ekonomi 14 (1): 20-25.

Robbins. 2007. Organizational behavior. Edisi Kedu. Singapore: Prentice Hall.

Schein, V. E. 2001. "The global look at psychological barriers to woman's progress in management." Journal of Social Sciences 57 (4): 675-88.

Silalahi. 2007. "Pengaruh pengetahuan kewirausahaan, motif berprestasi, dan kemandirian pribadi terhadap perilaku kewirausahaan." FE Universitas Sumatra Utara.

Siswoyo, B.B. 2009. "Pengembangan jiwa kewirausahaan di kalangan dosen dan mahasiswa." Jurnal Ekonomi Bisnis 14 (2): 114-23.

Suharto. 2005. Membangun masyarakat memberdayakan rakyat. Bandung: Rafika Aditama.

Sukirman. 2010. "Analisis pengaruh faktor internal dan eksternal terhadap kinerja usaha kecil yang dikelola perempuan (dengan pendekatan Balanced Scorecard)." Jurnal Kinerja, Bisnis dan Ekonomi 14 (3): 248-62.

—. 2012. "Analisis pengaruh kinerja lingkungan terhadap kinerja industri kecil.” Jurnal Dinamika Manajemen 3 (1): 10-18.

Sukirman, dan M. Indrayani. 2014. "Strategi pemberdayaan usaha kecil menuju kemandirian usaha dengan menerapkan manajemen profesional." Jurnal Ilmu 
Manajemen 4 (1): 1-14.

Suliyanto. 2006. Metode riset bisnis. Yogyakarta: Andi Offset.

Suryana. 2006. Kewirausahaan pedoman praktis, kiat dan proses menuju sukses. Jakarta: Salemba Empat.

Suseno, D. 2008. "Pengaruh karakteristik wirausaha dan potensi kewirausahaan terhadap keberhasilan usaha dengan kebijakan pengembanagan UKM sebagai moderating." Jurnal Ekonomi Bisnis 2 (4): 23-35.

Tambunan, Tulus. 2012. Usaha mikro kecil dan menengah di Indonesia (isu-isu penting). Jakarta: LP3ES.

Thobias, E. 2013. "Pengaruh modal sosial terhadap perilaku kewirausahaan (suatu studi pada pelaku usaha mikro kecil menengah di kecamatan Kabaruan kabupaten Kepulauan Talaud)." Journal ACTA DIURNA 2 (2): 1-12.

Welsch, Liao, dan Stoica. 2003. "Organizational absorptive capacity and responsiveness: An empirical investigation of growth-oriented SMEs." Journal Entrepreneurship Theory and Practice 28 (1): 63-85.

Zaheer. 2001. "Cluster capabilities or ethnic ties? location choice by foreign and domestic entrants in the services offshoring industry in India." Journal of International Business Studies 40 (6): 944-68. 